\title{
ISOTOPIC EVIDENCE FOR THE MIGRATION OF THERMOGENIC METHANE INTO A SULFIDIC CAVE, CUEVA DE VILLA LUZ, TABASCO, MEXICO
}

\author{
Kevin D. Webster ${ }^{1 *}$, Laura Rosales Lagarde ${ }^{2}$, Peter E. Sauer ${ }^{5}$, Arndt Schimmelmann ${ }^{5}$, Jay T. \\ LenNon $^{3}$, Penelope J. Boston ${ }^{4}$
}

\begin{abstract}
Methane $\left(\mathrm{CH}_{4}\right)$ is an economic resource and a greenhouse gas, but its migration through rocks is not immediately associated with speleogenesis. Sulfuric-acid speleogenesis is a cave-forming mechanism that has produced a variety of economically important oil fields and aquifers, and is theorized to be related to the oxidation of $\mathrm{CH}_{4}$ and hydrocarbons. Despite hypotheses that the oxidation of $\mathrm{CH}_{4}$ may provide a basis for the generation of sulfides during sulfuric-acid speleogenesis, evidence from active systems has not yet been obtained. In this study, we address how $\mathrm{CH}_{4}$ influences the development of sulfidic cave systems by sampling the $\mathrm{CH}_{4}, \mathrm{H}_{2} \mathrm{~S}$, and $\mathrm{CO}_{2}$ concentrations, as well as $\delta^{13} \mathrm{C}_{\mathrm{CH}_{4}}, \delta^{2} \mathrm{H}_{\mathrm{CH}_{4}}$, and $\delta^{13} \mathrm{C}_{\mathrm{CO}_{2}}$ values, in a cave currently forming by sulfuric-acid speleogenesis, Cueva de Villa Luz. $\mathrm{CH}_{4}, \mathrm{H}_{2} \mathrm{~S}$, and $\mathrm{CO}_{2}$ concentrations were highest directly above springs in the cave, showing that all three gases enter by means of the spring water. The $\delta^{13} \mathrm{C}_{\mathrm{CH}_{4}}$ and $\delta^{2} \mathrm{H}_{\mathrm{CH}_{4}}$ in the air of CVL ranged from $-47.92 \pm 0.15$ to $-35.47 \pm 0.12 \%$ (VPDB) and -117 to $-83 \%$ (VSMOW), respectively. Keeling plots suggest that $\mathrm{CH}_{4}$ with $\delta^{13} \mathrm{C}_{\mathrm{CH}_{4}}=-24 \pm 3 \%$ and $\delta^{2} \mathrm{H}_{\mathrm{CH}_{4}}=-40 \pm$ $50 \%$ was outgassing from spring water. This stable-isotope signature does not fall within traditional published $\delta^{13} \mathrm{C}_{\mathrm{CH}_{4}}$ versus $\delta^{2} \mathrm{H}_{\mathrm{CH}_{4}}$ fields. Our data suggest that the $\mathrm{CH}_{4}$ entering Cueva de Villa Luz is the remnant of a larger thermogenic $\mathrm{CH}_{4}$ flux that is incompletely oxidized in the subsurface as it travels to Cueva de Villa Luz. Our data support links between the processes forming Cueva de Villa Luz and the proposed mechanisms for other caves associated with sulfuric acid.
\end{abstract}

\section{INTRODUCTION}

The migration of subsurface methane $\left(\mathrm{CH}_{4}\right)$ through rock units toward the earth's surface creates natural gas deposits, contributes to the atmospheric $\mathrm{CH}_{4}$ burden, and supports microbial communities, but is rarely thought to alter the encountered rock units. However, $\mathrm{CH}_{4}$ and other hydrocarbons may enhance the porosity and permeability of limestones by fostering sulfuric-acid speleogenesis (Davis, 1980; Egemeier, 1981; Kirkland and Evans, 1976; Hill, 1990, 1995). As $\mathrm{CH}_{4}-$ rich fluids migrate within the subsurface and interact with evaporites, such as anhydrite or gypsum, they obtain sulfate $\left(\mathrm{SO}_{4}^{2-}\right)$ that may react with $\mathrm{CH}_{4}$ to form hydrogen sulfide $\left(\mathrm{H}_{2} \mathrm{~S}\right)$ :

$$
\begin{aligned}
& \mathrm{Ca}^{2+}+2 \mathrm{SO}_{4}^{2-}+2 \mathrm{CH}_{4}+2 \mathrm{H}^{+} \rightarrow 2 \mathrm{H}_{2} \mathrm{~S}+\mathrm{CaCO}_{3} \\
& \quad+3 \mathrm{H}_{2} \mathrm{O}+\mathrm{CO}_{2}
\end{aligned}
$$

The introduction of sulfide to oxygen in near-surface environments results in the formation of sulfuric acid $\left(\mathrm{H}_{2} \mathrm{SO}_{4}\right)$, a strong acid capable of rapidly dissolving limestone.

With some of the world's largest hydrocarbon deposits and aquifers hosted in sulfuric-acid dissolution-influenced limestones (Hill, 1995), a better understanding of how these caves form is important for finding new oil fields and drinking water. The suggestion that sulfuric-acid speleogenesis is associated with hydrocarbons originated from studies of Lower Kane Cave in Wyoming (Davis, 1980; Egemeier, 1981). Later, the morphologies and mineral assemblages of caves in the Guadalupe Mountains spurred hypotheses that these caves formed through sulfuric-acid speleogenesis (Hill, 1990, 1995; Peryt et al., 2012). The negative $\delta^{34} \mathrm{~S}$ values of hydrogen sulfide from springs and sulfide minerals in the caves suggested that microorganisms were responsible for the generation of the sulfides. Additionally, $\delta^{13} \mathrm{C}_{\mathrm{CO}_{2}}$ values from carbonates in these and other settings suggested that $\mathrm{CH}_{4}$ and hydrocarbons were oxidized in tandem with $\mathrm{SO}_{4}^{2-}$ reduction. Although the migration of $\mathrm{CH}_{4}$ is hypothesized to be important for the formation of sulfidic caves, to our knowledge no studies of these caves have measured $\mathrm{CH}_{4}$ concentrations in multiple locations from their entrances to their interiors, nor have measurements of both $\delta^{13} \mathrm{C}_{\mathrm{CH}_{4}}$ and $\delta^{2} \mathrm{H}_{\mathrm{CH}_{4}}$ values been made in a cave currently undergoing sulfuric-acid speleogenesis.

\footnotetext{
* Corresponding author: kevdwebs@indiana.edu

${ }^{1}$ Department of Ecology and Evolution, University of Arizona, 1041 E Lowell St., Tuscan, Az. 85719, USA

${ }^{2}$ Department of Earth and Atmospheric Sciences, Indiana University, $1001 \mathrm{E} 10^{\text {th }} \mathrm{St}$., Bloomington, IN 47405, USA

${ }^{3}$ Department of Physical and Life Sciences, Nevada State College, School of Liberal Arts and Sciences, 1021 Paradise Hills Drive, Ste. 246, Henderson, NV 89002, USA ${ }^{4}$ Department of Biology, Indiana University, 1001 E $3{ }^{\text {rd }}$ St., Bloomington, IN 47405, USA

${ }^{5}$ NASA Astrobiology Institute, NASA Ames Research Center, Moffett Field, CA 94035
} 
Stable-isotope ratios of carbon and hydrogen in $\mathrm{CH}_{4}$ provide a tool for understanding the origins and reactions of $\mathrm{CH}_{4}$ in the environment. For example, atmospheric $\mathrm{CH}_{4}$ has $\delta^{13} \mathrm{C}_{\mathrm{CH}_{4}}$ and $\delta^{2} \mathrm{H}_{\mathrm{CH}_{4}}$ values that are roughly $-47.5 \%$ (VPDB) and $-100 \%$ (VSMOW), respectively (Thom et al., 1993). Thermogenic $\mathrm{CH}_{4}$, which forms from the breakdown of organic matter by heat, has $\delta^{13} \mathrm{C}_{\mathrm{CH}_{4}}$ and $\delta^{2} \mathrm{H}_{\mathrm{CH}_{4}}$ values that generally range from -56 to $-20 \%$ and from -300 to $-70 \%$, respectively (Schoell, 1988; Whiticar, 1999). The original $\delta^{13} \mathrm{C}_{\mathrm{CH}_{4}}$ and $\delta^{2} \mathrm{H}_{\mathrm{CH}_{4}}$ values are altered during both biotic and abiotic $\mathrm{CH}_{4}$ oxidation; the former causes an increase of $8.5 \%$ in $\delta^{2} \mathrm{H}_{\mathrm{CH}_{4}}$ for each \%o increase in $\delta^{13} \mathrm{C}_{\mathrm{CH}_{4}}$ (Feisthauer et al., 2011). Thermochemical sulfate reduction, a form of abiotic methane oxidation, shows $\delta^{13} \mathrm{C}_{\mathrm{CH}_{4}}$ and $\delta^{2} \mathrm{H}_{\mathrm{CH}_{4}}$ values of roughly -30 and $-120 \%$ respectively (Liu et al., 2014). Furthermore, the mixing of $\mathrm{CH}_{4}$ from different sources can create $\mathrm{CH}_{4}$ with unusual isotopic ratios. For example, the Homorod mud volcano of Romania exhibits variations in $\delta^{2} \mathrm{H}_{\mathrm{CH}_{4}}$ values from -25 to $+30 \%$ that result from mixing between microbially produced $\mathrm{CH}_{4}$ and $\mathrm{CH}_{4}$ with a $\delta^{2} \mathrm{H}_{\mathrm{CH}_{4}}$ of $+124 \%$ generated from incomplete abiotic oxidation (Etiope et al., 2011).

$\mathrm{CH}_{4}$ has been measured from only two caves undergoing sulfuric-acid speleogenesis. The caves showed different characteristics. In Movile Cave in Romania, the $\mathrm{CH}_{4}$ in an isolated pocket of air between the cave's roof and a water body had a concentration of 10,000 ppmv and a $\delta^{13} \mathrm{C}_{\mathrm{CH}_{4}}$ value of $-60 \%$, indicating the presence of microbially generated $\mathrm{CH}_{4}$ (Sarbu et al., 1996; Hutchens et al., 2004). $\mathrm{CH}_{4}$ concentrations in Frasassi Cave in Italy ranged from 1.9 to 2.2 ppmv at a single collection site (Jones et al., 2012), although isotopic compositions were not reported. The current $\mathrm{CH}_{4}$ data set from sulfidic caves must be augmented in order to rigorously test current theories about hydrocarbon-driven sulfuric-acid speleogenesis.

We tested the hypothesis that hydrocarbons are fundamental in sulfuric-acid speleogenesis in the active Cueva de Villa Luz (CVL) system by measuring $\mathrm{CH}_{4}, \mathrm{H}_{2} \mathrm{~S}$, and $\mathrm{CO}_{2}$ concentrations and $\delta^{13} \mathrm{C}_{\mathrm{CH}_{4}}, \delta^{2} \mathrm{H}_{\mathrm{CH}_{4}}$, and $\delta^{13} \mathrm{C}_{\mathrm{CO}_{2}}$ values. If $\mathrm{CH}_{4}$ oxidation is responsible for the generation of $\mathrm{H}_{2} \mathrm{~S}$ in sulfidic caves, then abundances of $\mathrm{CH}_{4}, \mathrm{H}_{2} \mathrm{~S}$, and $\mathrm{CO}_{2}$ should be correlated in cave air as the gases follow the same pathway into the cave unless there are additional destruction or production mechanisms along the way. Additionally, the $\delta^{13} \mathrm{C}_{\mathrm{CH}_{4}}$ and $\delta^{2} \mathrm{H}_{\mathrm{CH}_{4}}$ values should show signs of oxidation, and $\delta^{13} \mathrm{C}_{\mathrm{CO}_{2}}$ values should be relatable to oxidized $\mathrm{CH}_{4}$. This study presents the first observations of $\mathrm{CH}_{4}$ concentrations along gradients from cave entrance to interior and of the stable-isotope ratios of hydrogen in $\mathrm{CH}_{4}$ in the air of an actively forming sulfidic cave.

\section{Geological Setting}

\section{Regional Geological Setting}

CVL is a shallow cave, has several natural openings, and is located in the Sierra de Chiapas $2 \mathrm{~km}$ south of Tapijulapa,
Tabasco, Mexico. It is hosted within a carbonate shelf of the middle Cretaceous Sierra Madre Formation (Rosales Lagarde et al., 2006; Fig. 1). The sedimentary record of the region spans from the Jurassic to the Tertiary and includes hydrocarbon formation (Aguilar Rodríguez, 2007; Clara Valdéz et al., 2009). Regional hydrocarbons, such as oils located about $50 \mathrm{~km}$ north of CVL, are presumably derived from Cretaceous marine limestones (Guzman-Vega and Mello, 1999).

Several potential sources of hydrogen sulfide $\left(\mathrm{H}_{2} \mathrm{~S}\right)$ are present in the CVL region. Possible sources of $\mathrm{H}_{2} \mathrm{~S}$ for $\mathrm{CVL}$ include the volcano El Chichón located $50 \mathrm{~km}$ west of CVL; petroleum basins located $50 \mathrm{~km}$ north of CVL such as the Macuspana and the Comalcalco basins; petroleum deposits within the Sierra de Chiapas; and economic sulfide deposits 25 $\mathrm{km}$ west of CVL (Pantoja-Alor, 1989; Hose et al., 2000; Rosales Lagarde et al., 2006, 2014; Fig. 1). However, sulfurisotope ratios of dissolved sulfide in the $\mathrm{H}_{2} \mathrm{~S}$-rich brackish springs of CVL range from -24 to $-6 \%$ Vienna Canyon Diablo Troilite (VCDT) and indicate that biological sulfate reduction of anhydrite-derived sulfate is the main mechanism producing the hydrogen sulfide in the groundwater column feeding the cave (Rosales Lagarde, 2013).

The regional tectonic history includes periods of extension and compression resulting in large scale faulting, fracturing, and folding (Meneses-Rocha, 2001; Alcàntara García et al., 2004; García Palomo et al., 2006). The main passage of CVL follows the strike of east-northeast bedding planes of Cretaceous limestone. This limestone is folded into a northwest plunging anticline and cut by a thrust fault (Rosales Lagarde, 2013; Fig. 1). Faulting and fracturing seem to facilitate the upward migration of deeper fluids. Additionally, hydrocarbon seeps in the region are common (Aguilar Rodríguez, 2007; PEMEX, personal communication).

\section{Geomorphology and Geochemistry of Cueva de VILLA LuZ}

The cave's main entrance and twenty-four skylights connect the air of CVL with the atmosphere (Fig. 2) (Hose and Pisarowicz, 1999). CVL is a weakly hydrothermal system and has a slightly elevated mean annual cave-air temperature of $28{ }^{\circ} \mathrm{C}$ compared to the regional mean annual atmospheric temperature of $27^{\circ} \mathrm{C}$. Sulfide-rich springs release $\mathrm{H}_{2} \mathrm{~S}$ into the cave air, where it ranges in concentration from 1 to $40 \mathrm{ppmv}$ depending on location (Hose and Pisarowicz, 1999). CVL is known to experience strong $\mathrm{H}_{2} \mathrm{~S}$ and carbon monoxide outgassing events when the $\mathrm{H}_{2} \mathrm{~S}$ concentration may increase from $<12 \mathrm{ppmv}$ to $>240 \mathrm{ppmv}$ in less than 3 minutes (Kleina, and Hose, pers. comm.; Boston, unpub. results). The cause of these outgassing events is unknown.

CVL's twenty-six known internal springs broadly fall into two categories: (i) springs with $<4.3 \mathrm{mg} \mathrm{L}^{-1}$ dissolved $\mathrm{O}_{2}$ and $<0.1 \mathrm{mg} \mathrm{L}^{-1}$ dissolved $\mathrm{H}_{2} \mathrm{~S}$ and (ii) springs with $<0.1 \mathrm{mg} \mathrm{L}^{-1}$ dissolved $\mathrm{O}_{2}$ and 300 to $500 \mathrm{mg} \mathrm{L}^{-1}$ dissolved $\mathrm{H}_{2} \mathrm{~S}$ (Hose et al., 2000). Non-sulfidic springs have a higher temperature than 

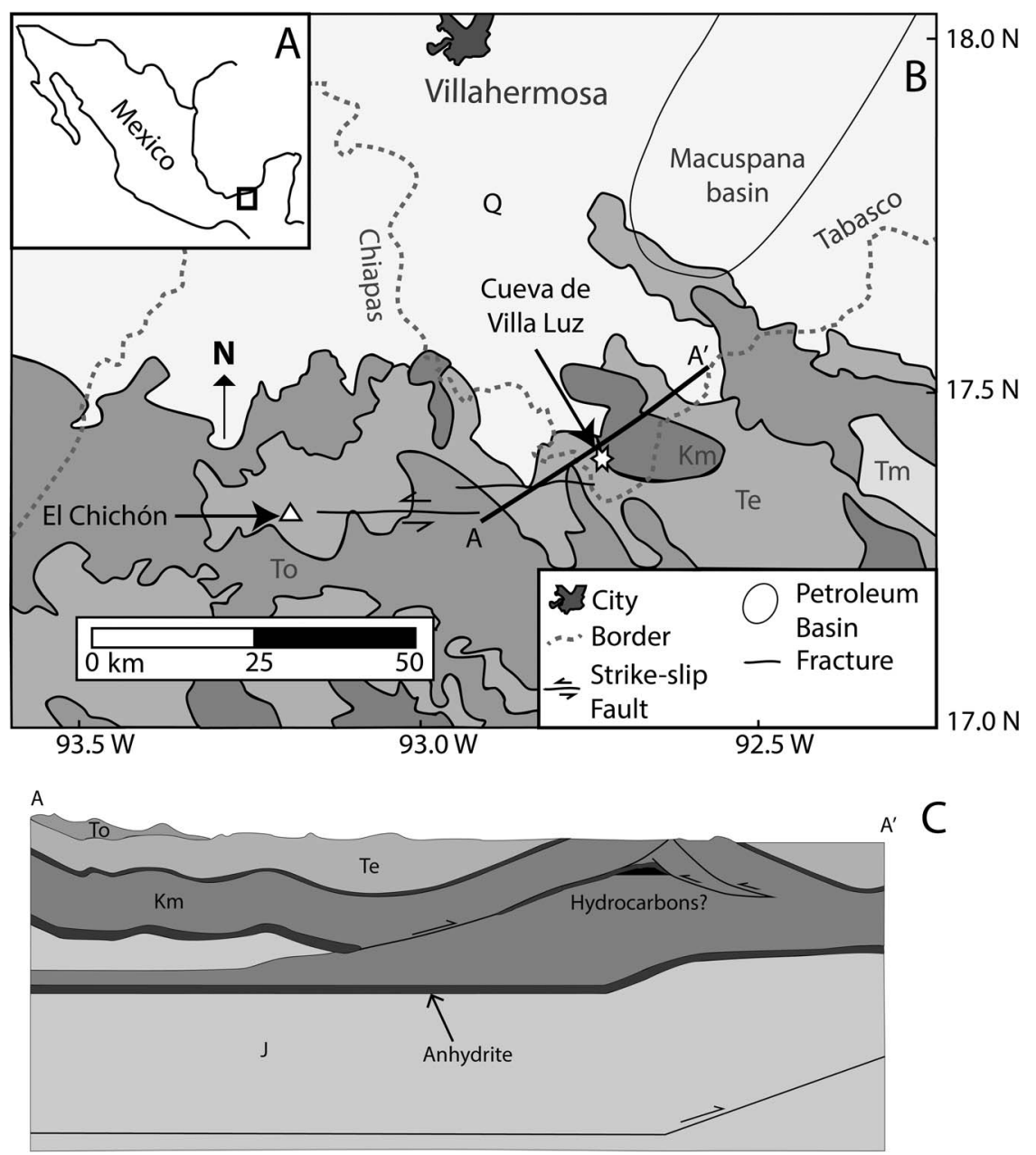

Figure 1. The regional setting of the study area showing A) the location of the study area in Mexico and B) geological features and units that may be influencing the $\mathrm{CH}_{4}$ concentrations in Cueva de Villa Luz. Q: Quaternary sediments; Te: Eocene units; To: Oligocene units; Tm: Miocene units; Km: Cretaceous units; J: Jurassic units. C) A cross-section from A to $\mathrm{A}^{\prime}$ showing lithological units in the region. This map has been redrawn from Alcàntara García et al. (2004) and the U.S. Geological Survey World Energy Assessment Team (2000).

those with sulfide (Rosales Lagarde, 2013). All springs are brackish, and the water chemistry is influenced by dissolution of limestone, dolomite, halite, and gypsum (Rosales Lagarde et al., 2014; Hose et al., 2000, Spilde et al., 2004).

\section{Methods}

\section{Air SAMPLing}

The geochemistry of cave air is affected by atmospheric conditions, which may dominate near entrances or skylights, and internal cave processes, which may dominate the chemistry in cave interiors (Peyraube et al., 2016). We sampled air in CVL using in-situ and discrete techniques. We used in-situ sampling to measure $\mathrm{H}_{2} \mathrm{~S}$ concentrations and obtained discrete air samples in $1 \mathrm{~L}$ Tedlar bags for later analysis of $\mathrm{CH}_{4}$ and $\mathrm{CO}_{2}$. We selected sampling locations based on their proximity to springs and entrances and measured the distances from each sampling location to the nearest entrance or spring based on the map of Hose and Pisarowicz (1999). Samples were defined as "near a spring" if they were obtained $<2 \mathrm{~m}$ from a spring and samples were defined as "near an entrance" if they were $<10 \mathrm{~m}$ from an entrance.

We measured $\mathrm{H}_{2} \mathrm{~S}$ concentrations with a GasBadge Pro $\mathrm{H}_{2} \mathrm{~S}$ instrument (Industrial Scientific, Pasadena, Texas) and a Ventis MX4 device (Industrial Scientific, Pasadena, Texas) from nine locations in CVL (Fig. 2) (Table 1). We measured $\mathrm{H}_{2} \mathrm{~S}$ concentrations at several elevations above the stream to assess the extent to which exsolution of $\mathrm{H}_{2} \mathrm{~S}$ from spring waters altered the concentration of $\mathrm{H}_{2} \mathrm{~S}$ in cave air. When data were measured with both the GasBadge and the Ventis (Table 1), we took the average of the $\mathrm{H}_{2} \mathrm{~S}$ concentrations (average difference, Ventis - Gasbage $=-2$ ppmv). At locations 1 through 12 we obtained discrete air samples in the cave, and we also obtained a discrete air sample from the local atmosphere $20 \mathrm{~m}$ from the main entrance of CVL using 


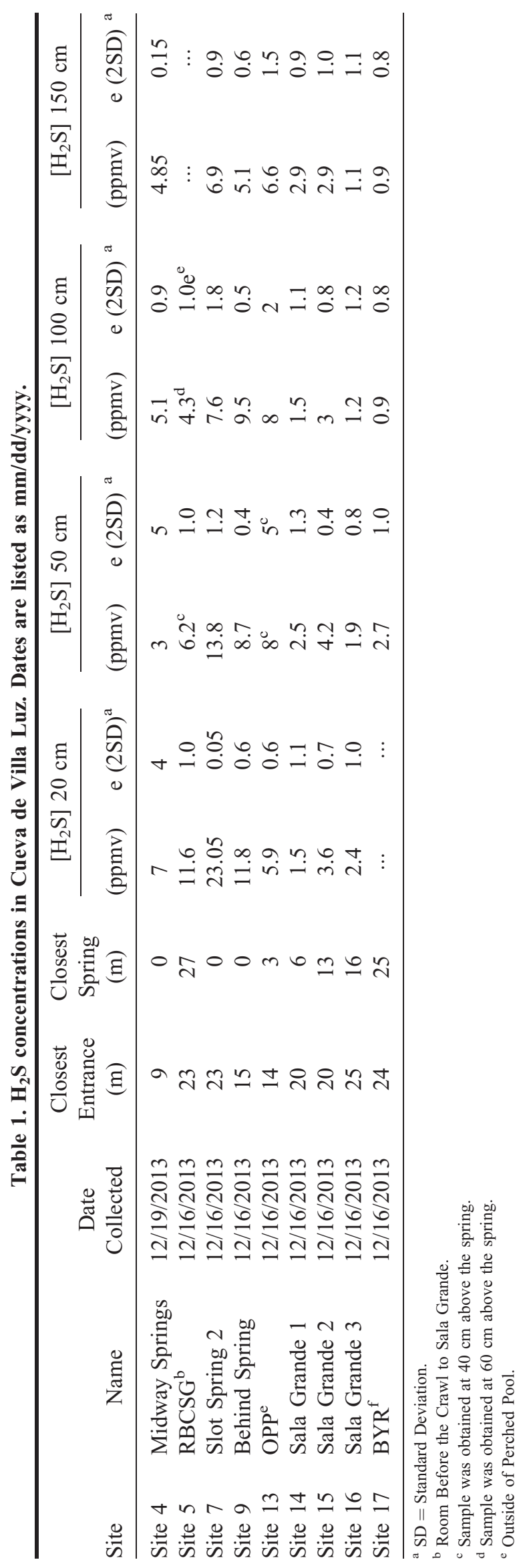

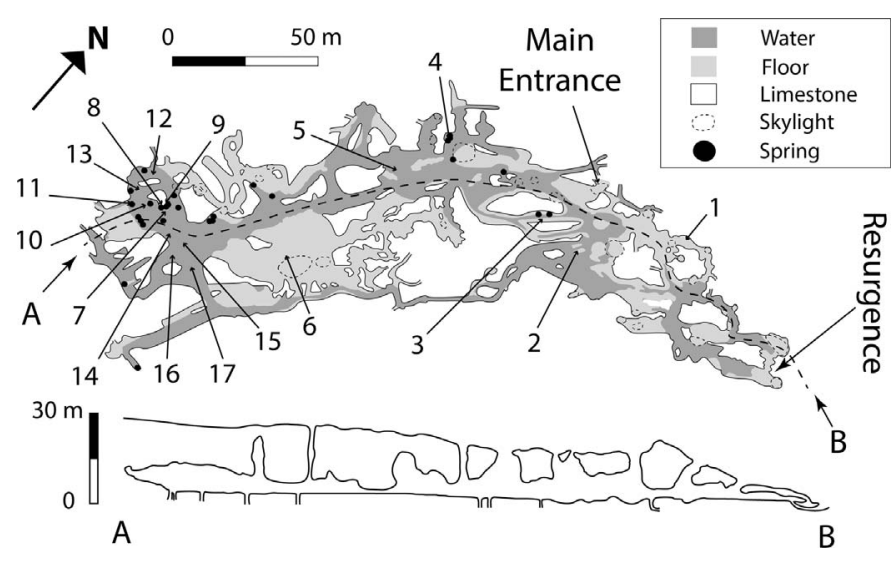

Figure 2. A simplified map of Cueva de Villa Luz in Mexico redrawn from Hose and Pisarowicz (1999). A cross-section of the cave's main passage is shown from A to B. Numerous skylights and springs are present in the cave. Arrows indicate air sample locations. Discrete air samples were obtained from sites 1 to 12 .

standard air-sampling techniques (Fig. 2) (Webster et al., 2016). All discrete cave-air samples from locations near springs were obtained $30 \mathrm{~cm}$ above the springs.

\section{LABORATORY ANALYSES}

We measured $\mathrm{CH}_{4}$ and $\mathrm{CO}_{2}$ concentrations from discrete samples with a Varian 450 gas chromatograph (GC) (see Webster et al., 2016). $\mathrm{CH}_{4}$ and $\mathrm{CO}_{2}$ calibration curves for concentration and uncertainty estimates were calculated following the methods of Webster et al. (2016).

We measured the $\delta^{13} \mathrm{C}_{\mathrm{CH}_{4}}, \delta^{2} \mathrm{H}_{\mathrm{CH}_{4}}$ and $\delta^{13} \mathrm{C}_{\mathrm{CO}_{2}}$ values to help determine the sources of $\mathrm{CH}_{4}$ and $\mathrm{CO}_{2}$ entering CVL. $\delta^{13} \mathrm{C}_{\mathrm{CH}_{4}}, \delta^{2} \mathrm{H}_{\mathrm{CH}_{4}}$ and $\delta^{13} \mathrm{C}_{\mathrm{CO}_{2}}$ values were measured on a Thermo Finnigan Delta Plus XP isotope-ratio mass-spectrometer (IRMS). $\delta^{13} \mathrm{C}_{\mathrm{CH}_{4}}$ and $\delta^{2} \mathrm{H}_{\mathrm{CH}_{4}}$ values were measured in continuous-flow mode using a gas chromatography-oxidation/ pyrolysis-IRMS (GC-ox/pyr-IRMS) interface following previously published methods (Miller et al., 2002; Webster et al., 2016). $\delta^{13} \mathrm{C}_{\mathrm{CO}_{2}}$ was measured with a Thermo Finnigan GasBench II inlet connected to the IRMS.

Raw ${ }^{13} \mathrm{C} /{ }^{12} \mathrm{C}$ and ${ }^{2} \mathrm{H} / \mathrm{H}$ isotope ratios measured by the mass spectrometer were converted to conventional $\delta$-values using two-point calibrations. The in-house $\mathrm{CH}_{4}$ reference materials were calibrated against international measurement standards NBS 19, LSVEC, VSMOW, and SLAP. Reference materials had $\delta^{13} \mathrm{C}_{\mathrm{CH}_{4}}$ values of $-38.25 \pm 0.06$ and $-58.64 \pm 0.15 \%$ and $\delta^{2} \mathrm{H}_{\mathrm{CH}_{4}}$ values of $-41 \pm 3$ and $-160 \pm 4 \%$, respectively. Analytical uncertainties of the $\delta^{13} \mathrm{C}_{\mathrm{CH}_{4}}$ and $\delta^{2} \mathrm{H}_{\mathrm{CH}_{4}}$ values of the $\mathrm{CH}_{4}$ reference materials ranged from \pm 0.07 to $\pm 0.15 \%$ (2 SD), and \pm 8 to $\pm 12 \%$ ( $2 \mathrm{SD}$ ), respectively, depending on the day of measurement, and these were assigned to data from air samples that were measured on the same day.

Raw ${ }^{13} \mathrm{C} /{ }^{12} \mathrm{C}$ ratios of $\mathrm{CO}_{2}$ were converted to $\delta^{13} \mathrm{C}_{\mathrm{CO}_{2}}$ values on the VPDB scale using a single standard with 


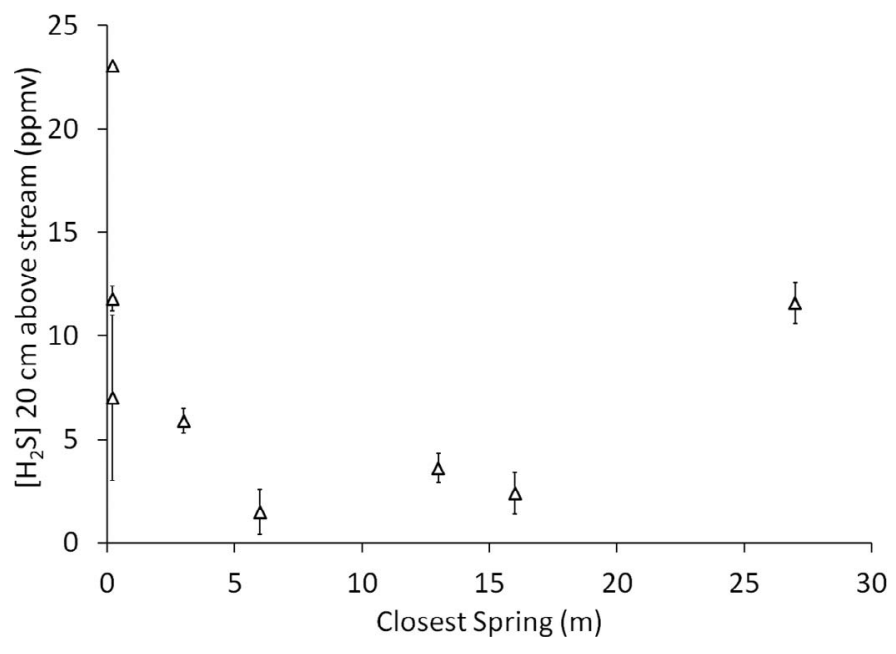

Figure 3. $\mathrm{H}_{2} \mathrm{~S}$ concentration in air $20 \mathrm{~cm}$ above the cave stream versus distance to the nearest spring in Cueva de Villa Luz. The elevated $\mathrm{H}_{2} \mathrm{~S}$ concentration at a distance of $28 \mathrm{~m}$ from a spring may be related to turbulent water entering from an adjacent room.

$\delta^{13} \mathrm{C}_{\mathrm{CO}_{2}}=-12.0 \pm 0.2 \%$. Samples and standards were measured ten times. Sample uncertainties were assessed using the methods of Webster et al. (2016).

\section{Quantitative AnAlyses}

Relationships between $\mathrm{CH}_{4}, \mathrm{CO}_{2}$, and $\mathrm{H}_{2} \mathrm{~S}$ concentrations and their distances to a spring were assessed through twosample $t$-tests assuming unequal variance. Additionally, correlations between $\mathrm{CH}_{4}$ and $\mathrm{CO}_{2}$ concentrations in the air of $\mathrm{CVL}$ were examined through regression analysis. The isotopic composition of the source of $\mathrm{CH}_{4}$ from cave springs was assessed using Keeling plots, as described in Thom et al. (1993). This approach assumes that gas samples represent varying mixtures of two gas end-members with contrasting $\mathrm{CH}_{4}$ concentrations and isotopic compositions. The $\delta^{13} \mathrm{C}_{\mathrm{CH}_{4}}$ and $\delta^{2} \mathrm{H}_{\mathrm{CH}_{4}}$ values of $\mathrm{CH}_{4}$ entering from springs were determined by the $y$-intercepts of linear regression analyses of $\delta^{13} \mathrm{C}_{\mathrm{CH}_{4}}$ and $\delta^{2} \mathrm{H}_{\mathrm{CH}_{4}}$ values of air samples versus $\left[\mathrm{CH}_{4}\right]^{-1}$ of the same samples (where $\left[\mathrm{CH}_{4}\right]$ is the concentration of $\mathrm{CH}_{4}$ in ppmv). Keeling plots were also used to determine the potential $\delta^{13} \mathrm{C}_{\mathrm{CO}_{2}}$ end member value of $\mathrm{CO}_{2}$ in $\mathrm{CVL}$ air following the methods of Rey et al. (2012).

\section{RESULTS}

$\mathrm{H}_{2} \mathrm{~S}$ concentrations in the air of CVL ranged from $0.9 \pm$ 0.8 to $23.05 \pm 0.05$ ppmv (Table 1 ) and were highest closest to springs (two-sample $t$-test unequal variance, $t_{14}=3.02, p=$ 0.005; Fig. 3). $\mathrm{CH}_{4}$ concentrations ranged from $1.88 \pm 0.10$ ppmv to $3.67 \pm 0.18 \mathrm{ppmv}(n=12)$, and $\mathrm{CO}_{2}$ concentrations ranged from $400 \pm 20 \mathrm{ppmv}$ to $920 \pm 50 \mathrm{ppmv}(n=12$; Fig. 4; Table 2). The concentrations of $\mathrm{CH}_{4}$ and $\mathrm{CO}_{2}$ in the local

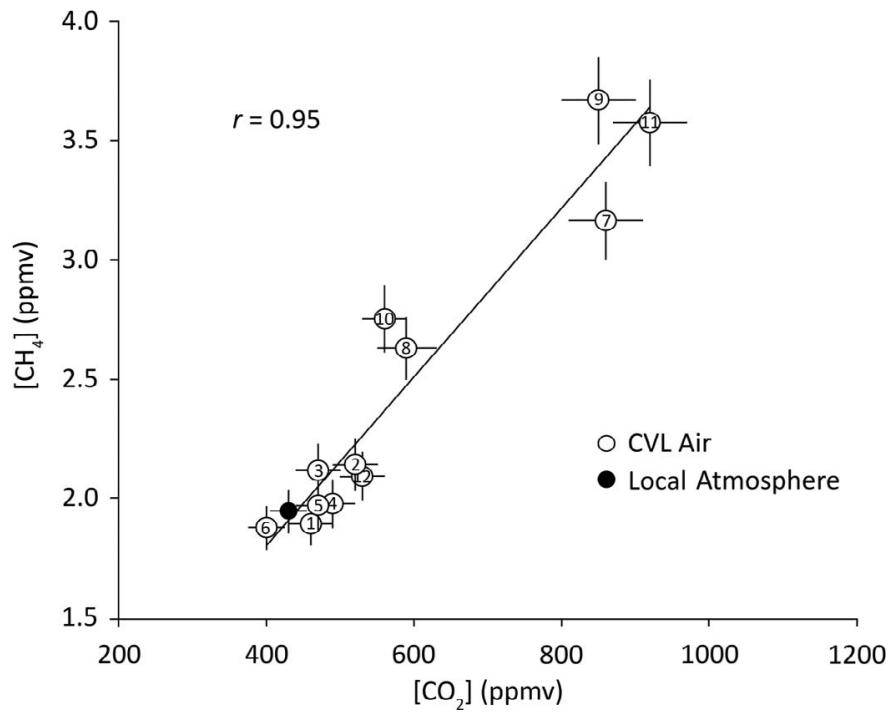

Figure 4. $\mathrm{CH}_{4}$ versus $\mathrm{CO}_{2}$ concentrations in Cueva de Villa Luz (CVL) showing a strong positive correlation $(r=0.95$, $n=12, p<0.01)$. Open circles represent CVL air samples, whereas the black circle represents the open atmosphere outside of the cave.

atmosphere were $1.96 \pm 0.10 \mathrm{ppmv}$ and $430 \pm 20 \mathrm{ppmv}$, respectively. $\mathrm{CH}_{4}$ and $\mathrm{CO}_{2}$ concentrations were positively correlated in the atmosphere of CVL $(r=0.95, n=12, p<$ 0.01 ; Fig. 4). $\mathrm{CH}_{4}$ and $\mathrm{CO}_{2}$ concentrations were higher at locations close to springs than at other locations $\left(\mathrm{CH}_{4}\right.$ : twosample $t$-test unequal variance, $t_{5}$ stat $=3.57, p=0.008, \mathrm{CO}_{2}$ : two-sample $t$-test unequal variance, $t_{6}$ stat $=3.05, p=0.01$; Fig. 5A). $\mathrm{CH}_{4}$ and $\mathrm{CO}_{2}$ concentrations were not related to the distance from an entrance $\left(\mathrm{CH}_{4}\right.$ : two-sample $t$-test unequal variance, $t_{5}$ stat $=-1.16, p=0.15 ; \mathrm{CO}_{2}$ : two-sample $t$-test unequal variance, $t_{3}$ stat $=-0.75, p=0.25$; Fig. 5B).

$\delta^{13} \mathrm{C}_{\mathrm{CO}_{2}}$ values ranged from $-12.0 \pm 0.2$ to $-8.7 \pm 0.4 \%$ (Table 3). Air samples near cave entrances showed the lowest concentrations of $\mathrm{CO}_{2}$ and had $\delta^{13} \mathrm{C}_{\mathrm{CO}_{2}}$ values around -9.6 to $-9.4 \%$. The $\delta^{13} \mathrm{C}$ of atmospheric $\mathrm{CO}_{2},-10.8 \pm 0.6 \%$, did not match the $\delta^{13} \mathrm{C}_{\mathrm{CO}_{2}}$ values of other samples with near atmospheric $\mathrm{CO}_{2}$ concentrations, nor samples of atmospheric $\mathrm{CO}_{2}$ from other studies (Peyraube et al., 2013; FernandezCortes et al., 2015), and was excluded from further analyses. As $\mathrm{CO}_{2}$ concentrations increased, their $\delta^{13} \mathrm{C}_{\mathrm{CO}_{2}}$ values diverged from the $\delta^{13} \mathrm{C}_{\mathrm{CO}_{2}}$ of low- $\mathrm{CO}_{2}$ samples (Table 3 ). The slope of $\delta^{13} \mathrm{C}_{\mathrm{CO}_{2}}$ data in a Keeling plot was not different from zero $\left(r^{2}=0.23, n=12, p=0.11\right)$.

The relationships between $\mathrm{CH}_{4}$ concentration and $\delta^{13} \mathrm{C}_{\mathrm{CH}_{4}}$ and $\delta^{2} \mathrm{H}_{\mathrm{CH}_{4}}$ values in CVL air fit a two end-member mixing model in Keeling plots (Fig. 6). $\delta^{13} \mathrm{C}_{\mathrm{CH}_{4}}$ ranged from -47.92 \pm 0.15 to $-35.47 \pm 0.12 \%$ and was linearly related to the inverse $\mathrm{CH}_{4}$ concentration $\left(\delta^{13} \mathrm{C}_{\mathrm{CH}_{4}}=[-45 \pm 7] \times\left[\mathrm{CH}_{4}\right]^{-1}+\right.$ $[-24 \pm 3], r^{2}=0.98, n=9, p<0.01$; Fig. $\left.6 \mathrm{~A}\right) . \delta^{2} \mathrm{H}_{\mathrm{CH}_{4}}$ ranged from $-117 \pm 9$ to $-65 \pm 12 \%$ and was linearly related to the inverse $\mathrm{CH}_{4}$ concentration $\left(\delta^{2} \mathrm{H}_{\mathrm{CH}_{4}}=[-140 \pm 80] \times\right.$ 
K.D. Webster, L. Rosales Lagarde, P.E. Sauer, A. Schimmelmann, J.T. Lennon, and P.J. Boston

Table 2. Sample collection dates and measurement dates for the concentrations of $\mathrm{CH}_{4}$ and $\mathrm{CO}_{2}$. Dates are listed as mm/dd/yyyy.

\begin{tabular}{|c|c|c|c|c|c|c|c|}
\hline \multirow[b]{2}{*}{ Site } & \multirow[b]{2}{*}{$\begin{array}{l}\text { Collection } \\
\text { Date }\end{array}$} & \multicolumn{3}{|c|}{$\mathrm{CH}_{4}$ concentration } & \multicolumn{3}{|c|}{$\mathrm{CO}_{2}$ Concentration } \\
\hline & & $\begin{array}{c}\text { Analysis } \\
\text { Date }\end{array}$ & $\begin{array}{l}\text { Conc. } \\
\text { (ppmv) }\end{array}$ & $\mathrm{e}(2 \mathrm{SD})^{\mathrm{a}}$ & $\begin{array}{c}\text { Analysis } \\
\text { Date }\end{array}$ & $\begin{array}{l}\text { Conc. } \\
\text { (ppmv) }\end{array}$ & $\mathrm{e}(2 \mathrm{SD})^{\mathrm{a}}$ \\
\hline Site 1 & $12 / 17 / 2013$ & $12 / 31 / 2013$ & 1.89 & 0.09 & $12 / 31 / 2013$ & 460 & 30 \\
\hline Site 2 & $12 / 17 / 2013$ & $12 / 31 / 2013$ & 2.14 & 0.11 & $12 / 31 / 2013$ & 520 & 30 \\
\hline Site 3 & $12 / 17 / 2013$ & $12 / 31 / 2013$ & 2.12 & 0.11 & $12 / 31 / 2013$ & 470 & 30 \\
\hline Site 3 & $12 / 17 / 2013$ & $12 / 31 / 2013$ & 2.03 & 0.10 & $12 / 31 / 2013$ & 450 & 30 \\
\hline Site 4 & $12 / 17 / 2013$ & $12 / 31 / 2013$ & 1.98 & 0.10 & $12 / 31 / 2013$ & 490 & 30 \\
\hline Site 5 & $12 / 16 / 2013$ & $12 / 31 / 2013$ & 1.97 & 0.10 & $12 / 31 / 2013$ & 470 & 30 \\
\hline Site 6 & $12 / 16 / 2013$ & $12 / 31 / 2013$ & 1.88 & 0.09 & $12 / 31 / 2013$ & 400 & 20 \\
\hline Site 7 & $12 / 16 / 2013$ & $12 / 31 / 2013$ & 3.16 & 0.16 & $12 / 31 / 2013$ & 860 & 50 \\
\hline Site 7 & $12 / 16 / 2013$ & $12 / 31 / 2013$ & 3.03 & 0.15 & $12 / 31 / 2013$ & 860 & 50 \\
\hline Site 8 & $12 / 16 / 2013$ & $12 / 31 / 2013$ & 2.63 & 0.13 & $12 / 31 / 2013$ & 590 & 40 \\
\hline Site 8 & $12 / 16 / 2013$ & $12 / 31 / 2013$ & 2.33 & 0.12 & $12 / 31 / 2013$ & 570 & 30 \\
\hline Site 9 & $12 / 16 / 2013$ & $12 / 31 / 2013$ & 3.67 & 0.18 & $12 / 31 / 2013$ & 850 & 50 \\
\hline Site 10 & $12 / 16 / 2013$ & $12 / 31 / 2013$ & 2.74 & 0.14 & $12 / 31 / 2013$ & 560 & 30 \\
\hline Site 11 & $12 / 17 / 2013$ & $12 / 31 / 2013$ & 3.58 & 0.18 & $12 / 31 / 2013$ & 920 & 50 \\
\hline Site 12 & $12 / 17 / 2013$ & $12 / 31 / 2013$ & 2.09 & 0.10 & $12 / 31 / 2013$ & 530 & 30 \\
\hline Outside Cave & $12 / 17 / 2013$ & $12 / 31 / 2013$ & 1.96 & 0.10 & $12 / 31 / 2013$ & 430 & 30 \\
\hline
\end{tabular}

${ }^{\mathrm{a}} \mathrm{SD}=$ Standard deviation.

$\left[\mathrm{CH}_{4}\right]^{-1}+[-40 \pm 50], r^{2}=0.62, n=8, p=0.02$; Fig. 6B). Air samples from locations nearest to entrances define one end-member of $\mathrm{CH}_{4}$ entering the cave with a $\delta^{13} \mathrm{C}_{\mathrm{CH}_{4}}$ of $-47.6 \pm 0.8 \%$ and a $\delta^{2} \mathrm{H}_{\mathrm{CH}_{4}}$ of $-112 \pm 14 \%$. Samples obtained near springs suggest a second source of $\mathrm{CH}_{4}$ entering CVL with a $\delta^{13} \mathrm{C}_{\mathrm{CH}_{4}}$ of $-24 \pm 3 \%$ and a $\delta^{2} \mathrm{H}_{\mathrm{CH}_{4}}$ of $-40 \pm 50 \%$ (Figs. 6, 7).

\section{DisCUSSION}

Hydrogen Sulfide, Methane, and Carbon Dioxide ENTER CVL From SpRINGS

The observed concentrations in $\mathrm{CVL}$ of $\mathrm{H}_{2} \mathrm{~S}, \mathrm{CH}_{4}$, and $\mathrm{CO}_{2}$, and the stable-isotope compositions of $\mathrm{CH}_{4}$ and $\mathrm{CO}_{2}$ result from a combination of airflow through the cave,

Table 3. Sample stable isotopic compositions of $\mathrm{CH}_{4}$ and $\mathrm{CO}_{2}$. Dates are listed as $\mathrm{mm} / \mathrm{dd} / \mathrm{yyyy}$.

\begin{tabular}{|c|c|c|c|c|c|c|c|c|c|c|}
\hline \multirow[b]{2}{*}{ Site } & \multirow[b]{2}{*}{$\begin{array}{l}\text { Collection } \\
\text { Date }\end{array}$} & \multicolumn{3}{|c|}{$\delta^{13} \mathrm{C}_{\mathrm{CH}_{4}}$} & \multicolumn{3}{|c|}{$\delta^{2} \mathrm{H}_{\mathrm{CH}_{4}}$} & \multicolumn{3}{|c|}{$\delta^{13} \mathrm{C}_{\mathrm{CO}_{2}}$} \\
\hline & & $\begin{array}{l}\text { Analysis } \\
\text { Dates }\end{array}$ & $\begin{array}{c}\% 0 \\
\text { (VPDB) }\end{array}$ & $\mathrm{e}(2 \mathrm{SD})^{\mathrm{a}}$ & $\begin{array}{l}\text { Analysis } \\
\text { Dates }\end{array}$ & $\begin{array}{c}\% \\
\text { (VSMOW) }\end{array}$ & e $(2 S D)^{a}$ & $\begin{array}{l}\text { Analysis } \\
\text { Date }\end{array}$ & $\begin{array}{c}\% \\
\text { (VPDB) }\end{array}$ & $\mathrm{e}(2 \mathrm{SD})^{\mathrm{a}}$ \\
\hline Site 1 & $12 / 17 / 2013$ & $4 / 9 / 2014$ & -47.26 & 0.12 & $\mathrm{LSV}^{\mathrm{b}}$ & ... & $\ldots$ & $1 / 9 / 2014$ & -9.4 & 0.2 \\
\hline Site 2 & $12 / 17 / 2013$ & $4 / 3 / 2014$ & -45.71 & 0.15 & $3 / 18 / 2014$ & -96 & 10 & $1 / 9 / 2014$ & -10 & 0.2 \\
\hline Site 3 & $12 / 17 / 2013$ & $4 / 3 / 2014$ & -46.51 & 0.15 & $3 / 19 / 2014$ & -97 & 12 & 1/9/2014 & -9.6 & 0.3 \\
\hline Site 4 & $12 / 17 / 2013$ & $\mathrm{SL}^{\mathrm{c}}$ & $\ldots$ & $\ldots$ & $\mathrm{LSV}^{\mathrm{b}}$ & $\ldots$ & $\cdots$ & $1 / 9 / 2014$ & -9.6 & 0.3 \\
\hline Site 5 & $12 / 16 / 2013$ & $4 / 4 / 2014$ & -45.73 & 0.07 & $3 / 18 / 2014$ & -116 & 10 & 1/9/2014 & -9.6 & 0.7 \\
\hline Site 6 & $12 / 16 / 2013$ & $4 / 3 / 2014$ & -47.92 & 0.15 & $3 / 21 / 2014$ & -117 & 9 & $1 / 9 / 2014$ & -9.5 & 0.3 \\
\hline Site 7 & $12 / 16 / 2013$ & $4 / 9 / 2014$ & -38.28 & 0.12 & $3 / 18 / 2014$ & -104 & 10 & $1 / 9 / 2014$ & -12 & 0.2 \\
\hline Site 8 & $12 / 16 / 2013$ & $4 / 3 / 2014$ & -42.45 & 0.15 & $3 / 19 / 2014$ & -87 & 12 & $1 / 9 / 2014$ & -10.6 & 0.2 \\
\hline Site 9 & $12 / 16 / 2013$ & $4 / 9 / 2014$ & -35.47 & 0.12 & $3 / 19 / 2014$ & -65 & 12 & $1 / 9 / 2014$ & -10.4 & 0.2 \\
\hline Site 9 & $12 / 16 / 2013$ & $10 / 9 / 2014$ & -39 & 3 & $\ldots$ & $\ldots$ & $\ldots$ & $\ldots$ & $\ldots$ & $\ldots$ \\
\hline Site 10 & $12 / 16 / 2013$ & $4 / 3 / 2014$ & -40.63 & 0.15 & $3 / 21 / 2014$ & -83 & 8 & $1 / 9 / 2014$ & -9.7 & 0.3 \\
\hline Site 11 & $12 / 17 / 2013$ & $\mathrm{SL}^{\mathrm{c}}$ & $\ldots$ & $\ldots$ & $\mathrm{LSV}^{\mathrm{b}}$ & $\ldots$ & $\ldots$ & $1 / 9 / 2014$ & -9.1 & 0.3 \\
\hline Site 12 & $12 / 17 / 2013$ & $\mathrm{SL}^{\mathrm{c}}$ & $\ldots$ & $\ldots$ & $\mathrm{LSV}^{\mathrm{b}}$ & $\ldots$ & $\ldots$ & $1 / 9 / 2014$ & -8.7 & 0.4 \\
\hline Outside Cave & $12 / 17 / 2013$ & $4 / 3 / 2014$ & -47.34 & 0.15 & $3 / 18 / 2014$ & -107 & 10 & $1 / 9 / 2014$ & $-10.8^{d}$ & $0.6^{\mathrm{d}}$ \\
\hline
\end{tabular}

\footnotetext{
${ }^{\mathrm{a}} \mathrm{SD}=$ Standard deviation.

b Sample was not measured due to low sample volume (LSV = low sample volume).

${ }^{c}$ The sample had leaked at the time of measurement ( $\mathrm{SL}=$ sample leakage $)$.

d This measurement did not agree with other measurements of low $\mathrm{CO}_{2}$ concentration air.
} 

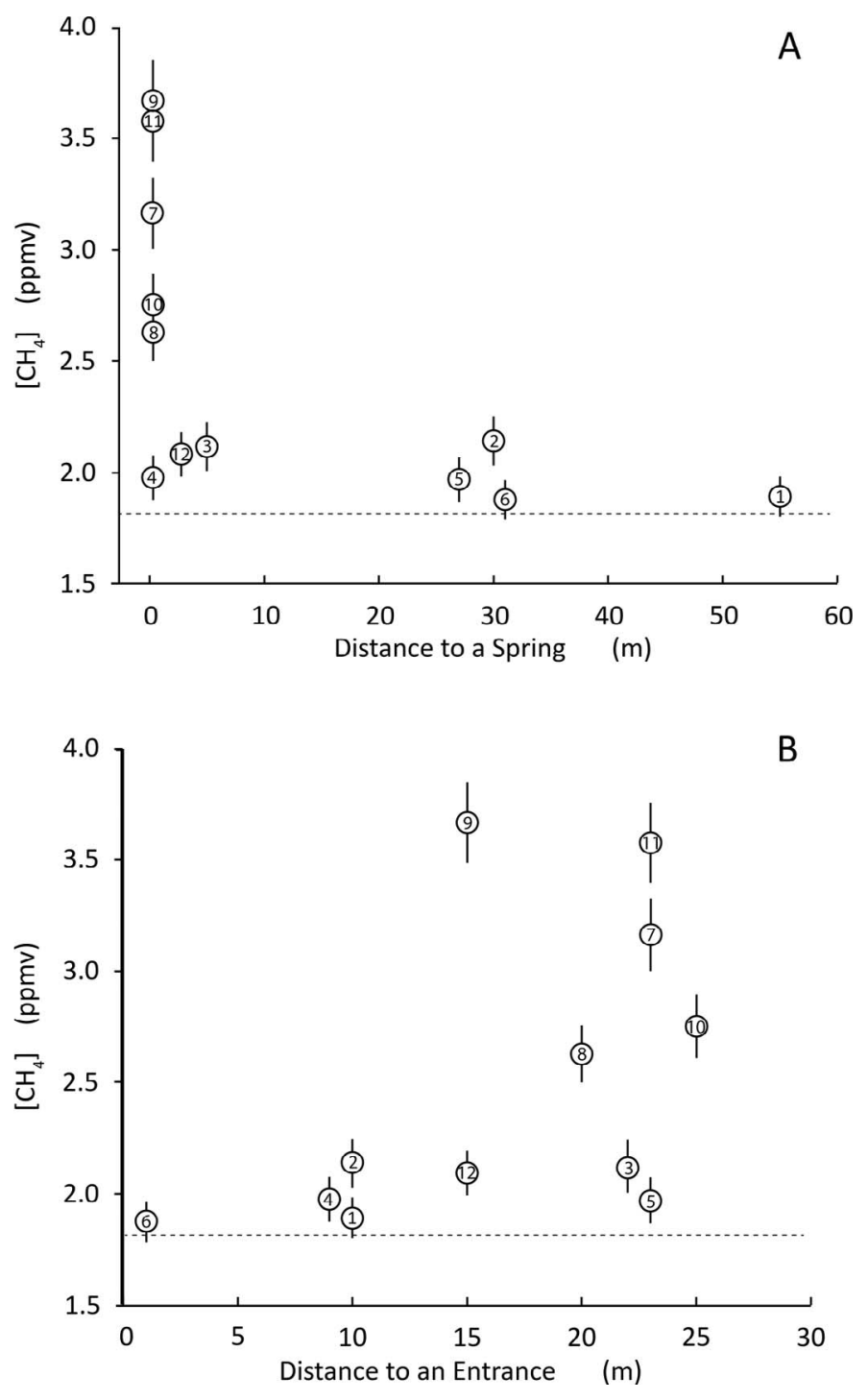

Figure 5. A) $\mathrm{CH}_{4}$ concentrations in cave air at different distances from springs. $\mathrm{B}) \mathrm{CH}_{4}$ concentrations in cave air at different distances from an entrance. Dashed lines indicate the global atmospheric average $\mathrm{CH}_{4}$ concentration (Adushkin and Kudryavtsev, 2013).

biogeochemical processes operating within the cave, and biogeochemical processes in the waters that feed the cave springs. The temperature of the open atmosphere at the time of sampling was lower than the temperature inside CVL, and cool air was felt entering from the skylights. This type of airflow should result in cave air composition near skylights that resembles the open atmosphere, as was observed in CVL at the time of sampling. Additionally, high rates of atmospheric exchange are indicated by roughly atmospheric $\mathrm{CH}_{4}$ and $\mathrm{CO}_{2}$ concentrations at sample sites that were neither close to an entrance nor immediately adjacent to springs.

Elevated $\mathrm{CH}_{4}$ and $\mathrm{CO}_{2}$ concentrations at springs imply that $\mathrm{CH}_{4}$ and $\mathrm{CO}_{2}$ are exsolving from spring water (Fig. 4). The only site located close to a spring that did not show elevated
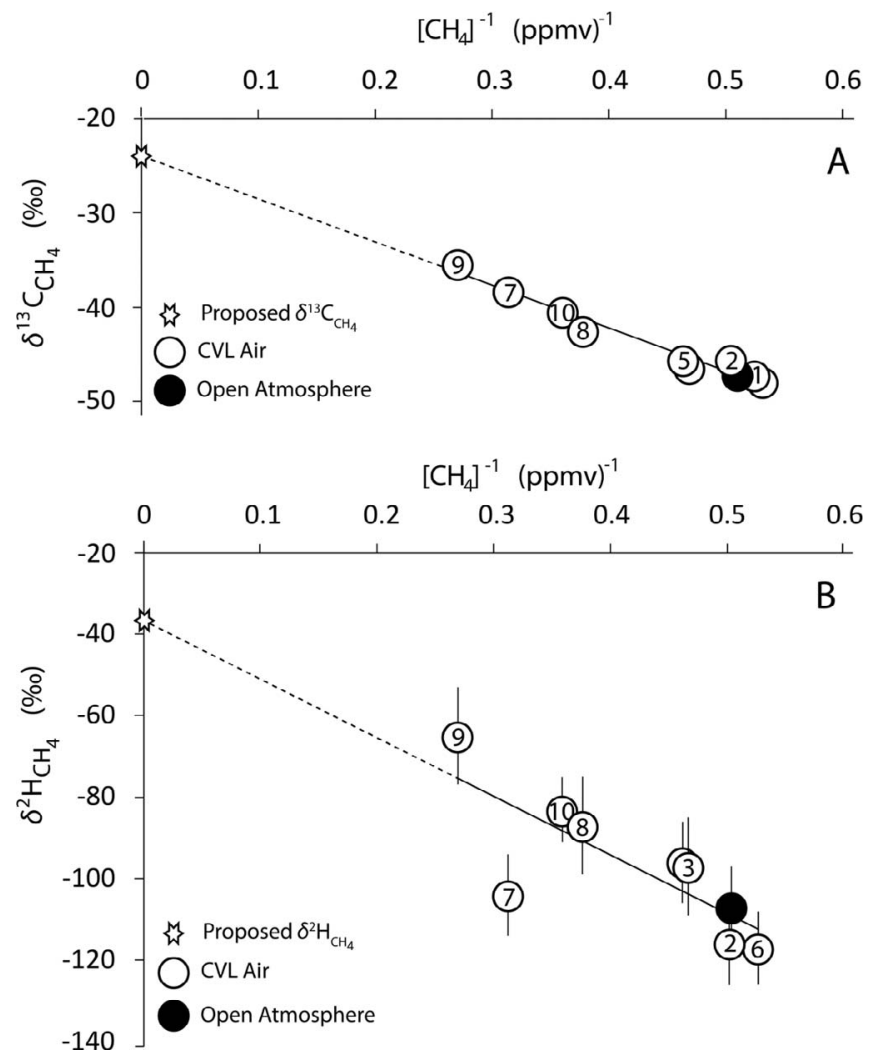

Figure 6. Keeling plot of $\delta^{13} \mathrm{C}_{\mathrm{CH}_{4}}$ from cave air $\left(\mathrm{A}, \delta^{13} \mathbf{C}_{\mathrm{CH}_{4}}\right.$ $=[-45 \pm 7] \times\left[\mathrm{CH}_{4}\right]^{-1}+[-24 \pm 3], r^{2}=0.98, n=9, p<$ $0.01)$ and $\delta^{2} \mathbf{H}_{\mathrm{CH}_{4}}\left(\mathrm{~B}, \delta^{2} \mathbf{H}_{\mathrm{CH}_{4}}=[-140 \pm 80] \times\left[\mathrm{CH}_{4}\right]^{-1}+\right.$ $[-40 \pm 50], r^{2}=0.62, n=8, p=0.02$. The error bars are smaller than the data points in A. The star marks the $y$ intercept that indicates the $\delta^{13} \mathrm{C}_{\mathrm{CH}_{4}}$ and $\delta^{2} \mathrm{H}_{\mathrm{CH}_{4}}$ of the dissolved $\mathrm{CH}_{4}$ in the spring water. The open circles represent Cueva de Villa Luz air samples, and black circles represent the outside atmosphere as measured during the study.

$\mathrm{CH}_{4}$ and $\mathrm{CO}_{2}$ concentrations was Midway Spring (Site 4), which is located $9 \mathrm{~m}$ from a skylight (Fig. 4). Elevated $\mathrm{CH}_{4}$ concentrations in cave air near springs have not been reported from other caves. The $\mathrm{CH}_{4}$ concentrations in CVL that were not located by springs (1.9 to $2.2 \mathrm{ppmv}$ ) are more similar to those measured in the sulfidic Frasassi Cave system (1.9 to 2.2 ppmv) in Italy (Jones et al., 2012) than they are to the sulfidic Movile Cave (10,000 ppmv) in Romania (Hutchens et al., 2004). This difference may be due to the lack of atmospheric connectivity at the site in Movile Cave, which is mostly waterfilled. We did not observe $\mathrm{CH}_{4}$ concentrations below 1.5 ppmv, as have been observed in many epigenic, non-sulfidic caves in Gibraltar, Australia, the United States, and Spain (Mattey et al., 2013; Fernandez-Cortes et al., 2015; McDonough et al., 2016; Webster et al., 2016; Lennon et al., 2016). Our results demonstrate that if in-situ $\mathrm{CH}_{4}$ oxidation processes were operating in CVL, they were not strong enough to react all of the $\mathrm{CH}_{4}$ in the collected samples. We can therefore 


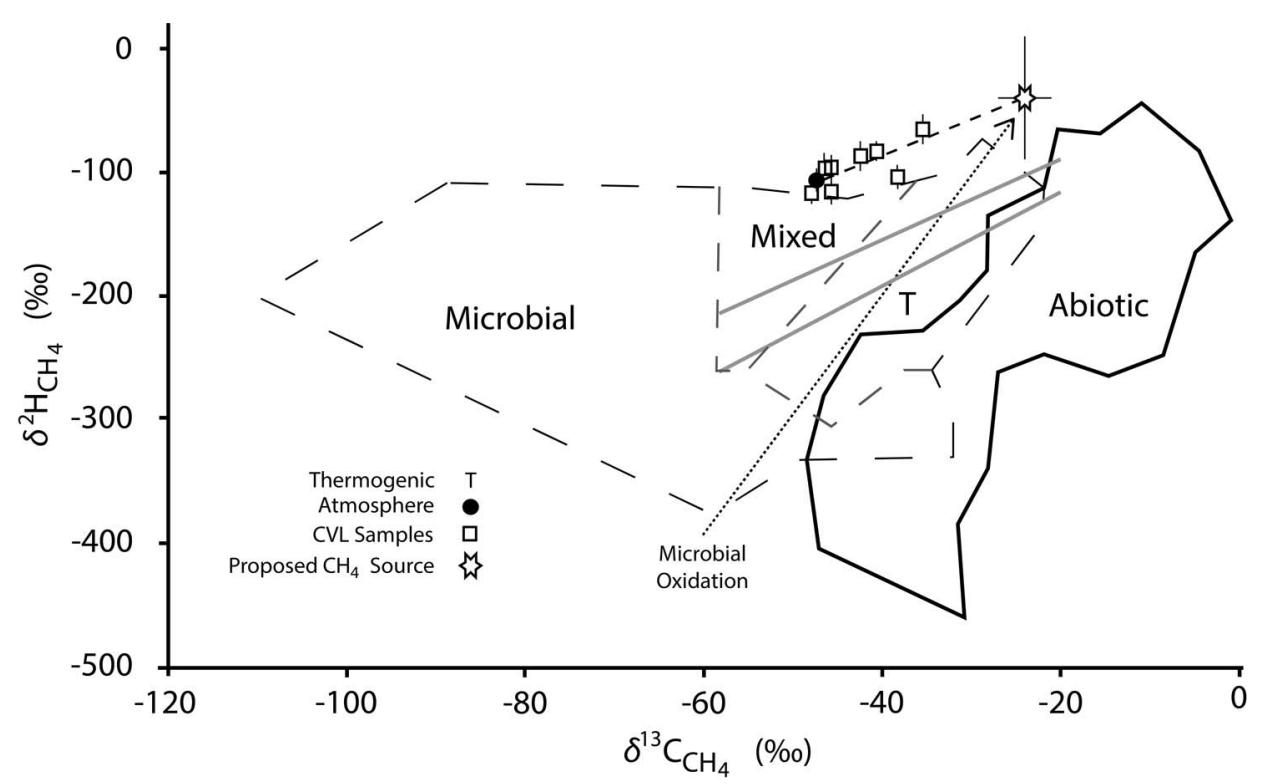

Figure 7. Isotopic characteristics of methane in air samples from Cueva de Villa Luz (CVL) plotted on published occurrence envelopes for microbial, thermogenic (T), and abiotic methanes (Etiope and Sherwood Lollar, 2013). Solid grey lines represent observed isotopic boundaries of methane from terrestrial and marine source rocks (Schoell, 1980). Data from CVL air samples (squares) plot along a bidirectional mixing line between an atmospheric source of $\mathrm{CH}_{4}$ and a methane entering CVL with a stable isotopic signature of $\delta^{13} \mathbf{C}_{\mathrm{CH}_{4}}=-24 \pm 3 \% 0, \delta^{2} \mathbf{H}_{\mathrm{CH}_{4}}=-40 \pm 50 \%$.

conclude that two most likely processes affecting $\mathrm{CH}_{4}$ in $\mathrm{CVL}$ are atmospheric circulation and spring-water outgassing.

\section{Stable Isotopic Composition and Sources of Methane}

The $\mathrm{CH}_{4}$ concentrations and values of $\delta^{13} \mathrm{C}_{\mathrm{CH}_{4}}$ and $\delta^{2} \mathrm{H}_{\mathrm{CH}_{4}}$ observed in $\mathrm{CVL}$ are consistent with mixing between an atmospheric $\mathrm{CH}_{4}$ source and a $\mathrm{CH}_{4}$ source entering from the springs. The lowest concentrations of $\mathrm{CH}_{4}$ in the air of $\mathrm{CVL}$ were measured at locations that were both close to entrances and far from springs. The $\delta^{13} \mathrm{C}_{\mathrm{CH}_{4}}$ and $\delta^{2} \mathrm{H}_{\mathrm{CH}_{4}}$ values from these locations plot near the respective values of atmospheric $\mathrm{CH}_{4}$ (Figs. 6, 7). The concentrations and isotopic composition of $\mathrm{CH}_{4}$ from the local atmosphere and cave locations near skylights agree with other measurements of atmospheric $\mathrm{CH}_{4}$ (Mikaloff Fletcher et al., 2004). The $\mathrm{CH}_{4}$ concentrations in CVL suggest that a secondary source of $\mathrm{CH}_{4}$ with a $\delta^{13} \mathrm{C}_{\mathrm{CH}_{4}}$ of $-24 \pm 3 \%$ and a $\delta^{2} \mathrm{H}_{\mathrm{CH}_{4}}$ of $-40 \pm 50 \%$ enters $\mathrm{CVL}$ dissolved in spring water. $\mathrm{CH}_{4}$ with this stable isotopic composition does not closely match known isotopic compositions generated by primary biotic or abiotic processes, and is driven largely by relatively positive $\delta^{2} \mathrm{H}_{\mathrm{CH}_{4}}$ values (Fig. 7).

The origin of the $\mathrm{CH}_{4}$ entering $\mathrm{CVL}$ at springs can be constrained in three ways, by comparing the $\mathrm{CH}_{4}$ isotopically to other $\mathrm{CH}_{4}$ sources in the region, by taking into account the regional thermal history, and by compensating for shifts in $\mathrm{CH}_{4}$ isotopic composition caused by oxidation. A possible explanation for $\delta^{13} \mathrm{C}_{\mathrm{CH}_{4}}$ values in cave air is that the $\mathrm{CH}_{4}$ entering CVL from the springs has an original isotopic composition with a $\delta^{13} \mathrm{C}_{\mathrm{CH}_{4}}$ value of $-24 \pm 3 \%$ and a $\delta^{2} \mathrm{H}_{\mathrm{CH}_{4}}$ value of $-40 \pm 50 \%$, based on the Keeling analysis. However, this $\delta^{13} \mathrm{C}_{\mathrm{CH}_{4}}$ of $\mathrm{CH}_{4}$ from CVL spring water is incompatible with $\mathrm{CH}_{4}$ from neighboring sedimentary basins, which have $\delta^{13} \mathrm{C}_{\mathrm{CH}_{4}}$ values of -32 to $-70 \%$ in the Macuspana Basin; -38 to $-45 \%$ in the Papaloapan Basin; -39 to $-55 \%$ in the Cuichapa Basin; and -40 to $-52 \%$ in the Reforma Basin (Clara Valdés et al., 2009). The most similar $\delta^{13} \mathrm{C}_{\mathrm{CH}_{4}}$ value from a regional natural gas well is about $-32 \%$ from the Macuspana Basin (Talukdar et al., 2002; Clara Valdés et al., 2009). Additionally, the proposed $\delta^{2} \mathrm{H}_{\mathrm{CH}_{4}}$ value of $\mathrm{CH}_{4}$ entering CVL from springs is very positive compared to values from the literature (Schoell, 1980; Etiope et al., 2011; Etiope and Sherwood Lollar et al., 2013). The evidence implies that a parental $\mathrm{CH}_{4}$ with the proposed $\delta^{13} \mathrm{C}_{\mathrm{CH}_{4}}$ and $\delta^{2} \mathrm{H}_{\mathrm{CH}_{4}}$ values is unlikely, and supports the idea that $\mathrm{CH}_{4}$ entering $\mathrm{CVL}$ in springs is the remnant of a larger $\mathrm{CH}_{4}$ flux at depth that has been mostly oxidized to $\mathrm{CO}_{2}$ on the way to the cave.

The thermal history of the CVL region provides a way to help determine whether abiotic or biotic oxidation is most likely to have altered the $\mathrm{CH}_{4}$ entering $\mathrm{CVL}$, because the temperature ranges at which they occur do not overlap. The minimum temperature for the onset of abiotic $\mathrm{CH}_{4}$ oxidation has been estimated to range from 100 to $140{ }^{\circ} \mathrm{C}$, whereas microbial $\mathrm{CH}_{4}$ oxidation (methanotrophy) generally takes place from 0 to $80{ }^{\circ} \mathrm{C}$ (Machel, 1998, 2001; Worden et al., 1995; Holler et al., 2011). Vitrinite reflectance $\left(\mathrm{R}_{\mathrm{o}}\right)$ data from source rocks in the region range from 0.5 to $0.8 \%$ (GuzmanVega and Mello, 1999) and correspond to maximum 
subsurface temperatures of 60 to $90{ }^{\circ} \mathrm{C}$ (Bjørlykke, 1989). Additionally, modern water temperatures from oil wells in the region $\left(30\right.$ to about $60{ }^{\circ} \mathrm{C}$ ) and dissolved silica geothermometers from ground water in the region do not suggest that volcanic heat flow is affecting groundwater temperature (Nencetti et al., 2005). These observations suggest that methanotrophy is responsible for consuming $\mathrm{CH}_{4}$ in the subsurface before entering CVL.

Correcting for the expected isotopic shifts associated with partial methanotrophic loss of $\mathrm{CH}_{4}$ can hindcast the original isotopic composition and reveal the origin of $\mathrm{CH}_{4}$ entering CVL. Microbial oxidation imparts an increase of about $8.5 \%$ in the $\delta^{2} \mathrm{H}_{\mathrm{CH}_{4}}$ value for every increase of $1 \%$ in the $\delta^{13} \mathrm{C}_{\mathrm{CH}_{4}}$ value (Feisthauer et al., 2011). If methanotrophy is assumed to be occurring in the subsurface, then the original stable isotopic composition of the $\mathrm{CH}_{4}$ entering $\mathrm{CVL}$ is hindcast to match a thermogenic source (Fig. 7).

\section{Possible Electron Acceptors for Methane OxiDATION}

The co-occurrence of $\mathrm{CH}_{4}$ and $\mathrm{H}_{2} \mathrm{~S}$ supports our claim that sulfate is the most likely electron acceptor, but what about other potential acceptors? Alternative electron acceptors such as $\mathrm{O}_{2}$, and nitrate $\left(\mathrm{NO}_{3}^{-}\right)$are known to be metabolically coupled to $\mathrm{CH}_{4}$ oxidation in other environments ( $\mathrm{Hu}$ et al., 2011; Mattey et al., 2013). However, $\mathrm{O}_{2}$ and $\mathrm{NO}_{3}^{-}$ concentrations in the anoxic springs of $\mathrm{CVL}$ were below detection in previous studies, where the concentration of each was $<0.1 \mathrm{mg} \mathrm{L}^{-1}$ (Hose et al., 2000; Rosales Lagarde et al., 2014). Addionally, organoclastic sulfate reduction competes with anaerobic $\mathrm{CH}_{4}$ oxidation only when organic matter is abundant ( $\sim 1 \%$ by sediment weight) (Malinverno and Pohlman 2011; Pohlman et al., 2013), and the organic carbon concentration in CVL spring water is comparatively low, ranging from 0.5 to $3.5 \mathrm{mg} \mathrm{L}^{-1}$ (Rosales Lagarde, 2013).

\section{Stable Isotopic Composition and Sources of Carbon Dioxide}

The $\delta{ }^{13} \mathrm{C}_{\mathrm{CO}_{2}}$ values near springs suggest that oxidized $\mathrm{CH}_{4}$ is not the primary contributor to dissolved $\mathrm{CO}_{2}$ in the spring water. The lowest $\mathrm{CO}_{2}$ concentration in CVL (Site 6, $1 \mathrm{~m}$ from an entrance) had a $\delta^{13} \mathrm{C}_{\mathrm{CO}_{2}}$ value of $-9.5 \pm 0.3 \%$ which matches known atmospheric $\mathrm{CO}_{2}$ concentrations $(400 \pm 20$ ppmv) and $\delta^{13} \mathrm{C}_{\mathrm{CO}_{2}}$ values (-10\%) (Peyraube et al., 2013; Fernandez-Cortes et al., 2015). The two highest $\mathrm{CO}_{2}$ concentrations in CVL at Site 11 (Sulfur Spring) and Site 7 (Slot Spring) were associated with the second-most-positive $\delta^{13} \mathrm{C}_{\mathrm{CO}_{2}}$ value of $-9.1 \pm 0.3 \%$ at Site 11 and the most negative $\delta^{13} \mathrm{C}_{\mathrm{CO}_{2}}$ value of $-12.0 \pm 0.2 \%$ at Site 7 . Processes that may cause diverging $\delta^{13} \mathrm{C}_{\mathrm{CO}_{2}}$ values of $\mathrm{CO}_{2}$ near springs include the oxidation of $\mathrm{CH}_{4}$ and other organic compounds, which are typically ${ }^{13} \mathrm{C}$-depleted, and the dissolution of marine carbonates, like those that host CVL, that have $\delta^{13} \mathrm{C}$ values from 1 to $4 \%$ (Keith and Weber, 1964; Knauth and Kennedy, 2009). $\delta^{13} \mathrm{C}_{\mathrm{CO}_{2}}$ values of the air above these springs are similar to the $\delta^{13} \mathrm{C}$ values of -9 to $-12 \%$ for dissolved $\mathrm{CO}_{2}$ measured in sulfidic springs $45 \mathrm{~km}$ northwest of CVL (Nencetti et al. 2005). The similarity of $\delta^{13} \mathrm{C}_{\mathrm{CO}_{2}}$ ranges from both areas demonstrate that processes causing diverging $\delta^{13} \mathrm{C}_{\mathrm{CO}_{2}}$ values at high $\mathrm{CO}_{2}$ concentrations are regional rather than specific to CVL.

\section{Comparison With Other Sulfidic Cave Systems}

Our proposed model of $\mathrm{CH}_{4}$ migration into $\mathrm{CVL}$ from petroleum basins not only provides sufficient $\mathrm{CH}_{4}$, but also agrees with proposed pathways of sulfur migration into CVL (Rosales Lagarde et al., 2014). The entrance of thermogenic $\mathrm{CH}_{4}$ into CVL also agrees with observations of $\mathrm{CH}_{4}$ and longer-chain hydrocarbons emanating from "Group II" springs of the Sierra de Chiapas region northwest of CVL (Nencetti et al., 2005). The $\mathrm{CH}_{4}$ /ethane molecular ratios from these springs generally match the $\mathrm{CH}_{4}$ /ethane ratios from petroleum basins when the ratios from springs are corrected for the differential solubility of $\mathrm{CH}_{4}$ and ethane in water (Clara Valdés et al., 2009; Dai et al., 2014). More broadly, a thermogenic source of $\mathrm{CH}_{4}$ suggests that the processes forming CVL are analogous to those that are thought to have formed Lower Kane Cave and the caves of the Guadalupe Mountains (Kirkland and Evans, 1976; Davis, 1980; Hill, 1995).

\section{Conclusions}

High $\mathrm{CH}_{4}, \mathrm{H}_{2} \mathrm{~S}$, and $\mathrm{CO}_{2}$ concentrations occur in cave air near springs in CVL, demonstrating that the three gases entered in solution via spring water. The poor match of the proposed stable isotopic signature of $\mathrm{CH}_{4}$ entering $\mathrm{CVL}$ from springs $\left(\delta^{13} \mathrm{C}_{\mathrm{CH}_{4}}=-24 \pm 3 \%\right.$, $\delta^{2} \mathrm{H}_{\mathrm{CH}_{4}}=-40 \pm 50 \%$ ) with known $\delta^{13} \mathrm{C}_{\mathrm{CH}_{4}}$ values from other studied systems and the thermal history of the region implies that the $\mathrm{CH}_{4}$ is of a secondary origin, with subterranean anaerobic methanotrophy as the most likely explanation. If methanotrophy is altering the $\mathrm{CH}_{4}$ as it traveled to $\mathrm{CVL}$, the original source of the $\mathrm{CH}_{4}$ is mathematically predicted to have a thermogenic origin. The incomplete oxidation of $\mathrm{CH}_{4}$ in the presence of sulfate appears to be generating the $\mathrm{H}_{2} \mathrm{~S}$ that enters $\mathrm{CVL}$ with spring water. This evidence for $\mathrm{CH}_{4}$ migrating from regional petroleum basins while being oxidized in the presence of sulfates connects the geochemical processes that are forming CVL to other caves, like those of the Guadalupe Mountains and Lower Kane Cave, whose origins have been attributed to sulfuric acid speleogenesis.

\section{ACKNOWLedgements}

The authors thank the National Geographic Society Expeditions Council for support (Grant \#EC0644-13 to PJB) as well as the authorities and inhabitants of the Tacotalpa municipality and the town of Tapijulapa. This material is 
based upon work supported by the U.S. Department of Energy, Office of Science, Office of Basic Energy Sciences, Chemical Sciences, Geosciences, and Biosciences Division under Award Number DE-SC0006978. This study forms part of the collaboration between the Universidad Juárez Autónoma de Tabasco and the New Mexico Institute of Mining and Technology. M.N. Spilde and D.E. Northup aided in discussions on previous work carried out in CVL. P.L. Griffin provided helpful insight during many discussions about stable isotope fractionation. T.V. Royer made analytical gas chromatography available. C. Gassaway edited a version of this manuscript. The comments of anonymous reviewers improved the quality of this manuscript.

\section{References Cited}

Adushkin, V.V., and Kudryavtsev, V.P., 2013, Estimating the global flux of methane into the atmosphere and its seasonal variations: Izvestiya, Atmospheric and Oceanic Physics, v. 49, no. 2, p. 128-136. https://doi.org/ $10.1134 / \mathrm{S} 0001433813020023$.

Aguilar Rodríguez, A., 2007, Presencia de hidrocarburos en el municipio de Tacotalpa, Tabasco: Horizonte Eploratorio, v. July-September 2007, p. 59.

Alcàntara García, J.R., Ham Wong, J.M., Medina Flores, U., Hernàndez Peñaloza, J.J., de la Cruz Rivera, V.M., Peña Ramirez, H., Namson, J., and Spaw, J.M., 2004, Identification and evaluation of plays in the Simojovel Project, southeastern Mexico: American Association of Petroleum Geologists International Conference October 24-27, 2004, Cancun, Mexico. abstract a90217, $6 \mathrm{p}$.

Bjørlykke, K., 1989, Sedimentology and Petroleum Geology. Berlin Heidelberg, Springer-Verlag, $363 \mathrm{p}$.

Clara Valdés, M.d.L., Villanueva Rodríguez, L., and Caballero García, E., 2009 , Geochemical integration and interpretation of source rocks, oils, and natural gases in southeastern Mexico: in Bartolini, C., and Román Ramos, J.R., eds., Petroleum Systems in the Southern Gulf of Mexico: AAPG Memoir, v. 90, p. 337-368. https://doi.org/10.1306/13191091M903337.

Dai, JinXing, Ni, YunYan, Hu, GuoYi, Huang, ShiPeng, Liao, FengRong, Yu, Cong, Gong, DeYu, and Wu, Wei, 2014, Stable carbon and hydrogen isotopes of gases from the large tight gas fields in China: Science China Earth Sciences, v. 57, no. 1, 88-103. https://doi.org/10.1007/ s11430-013-4701-7.

Davis, D.G., 1980, Cave development in the Guadalupe Mountains: a critical review of recent hypotheses: NSS Bulletin, v. 42, no. 3, p. 42-48.

Egemeier, S.J., 1981, Cavern development by thermal waters: National Speleological Society Bulletin, v. 43, p. 31-51.

Etiope, G., Baciu, C.L., and Schoell, M., 2011, Extreme methane deuterium, nitrogen and helium enrichment in natural gas from the Homorod seep (Romania): Chemical Geology, v. 280, p. 89-96. https://doi.org/10.1016/j. chemgeo.2010.10.019.

Etiope, G., and Sherwood Lollar, B., 2013, Abiotic methane on earth: Reviews of Geophysics, v. 51, no. 2, p. 276-299. https://doi.org/10.1002/rog.20011.

Feisthauer, S., Vogt, C., Modrzynski, J., Szlenkier, M., Krüger, M., Siegert, M., and Richnow, H.-H., 2011, Different types of methane monooxygenases produce similar carbon and hydrogen isotope fraction patterns during methane oxidation: Geochimica et Cosmochimica Acta, v. 75, no. 5, p. 1173-1184. https://doi.org/10.1016/j.gca.2010.12.006

Fernandez-Cortes, A., Cuezva, S., Alvarez-Gallego, M., Garcia-Anton, E., Pla, C., Benavente, D., Jurado, V., Saiz-Jimenez, C., and Sanchez-Moral, S., 2015, Subterranean atmospheres may act as daily methane sinks: Nature Communications, v. 6, no. 7003. https://doi.org/10.1038/ncomms8003.

García-Palomo, A., Macías, J.L., Arce, J.L., Mora, J.C., Hughes, S., Saucedo, R., Espíndola, J.M., Escobar, R., and Layer, P., 2006, Geological evolution of the Tacaná Volcanic Complex, México-Guatemala: in Rose, W.I., Bluth, G.J.S., Carr, M.J., Ewert, J.W., patino, L.C., and Vallance, J.W., eds., Volcanic Hazards in Central America, Geological Society of America Special Paper 412, p. 39-57. https://doi.org/10.1130/2006.2412(03).

Guzman-Vega, M.A., and Mello, M.R., 1999, Origin of oil in the Sureste Basin, Mexico: AAPG Bulletin, v. 83, no. 7, p. 1068-1095.
Hill, C.A., 1990, Sulfuric acid speleogenesis of Carlsbad Cavern and its relationship to hydrocarbons, Delaware Basin, New Mexico and Texas: AAPG Bulletin, v. 74, no. 11, p. 1685-1694.

Hill, C.A., 1995, Sulfur redox reactions: Hydrocarbons, native sulfur, Mississippi Valley-type deposits, and sulfuric acid karst in the Delaware Basin, New Mexico and Texas: Environmental Geology, v. 25, p. 16-23. https://doi.org/10.1007/BF01061826.

Holler, T., Widdel, F., Knittel, K., Amann, R., Kellermann, M.Y., Hinrichs, K.-U., Teske, A., Boetius, A., and Wegener, G., 2011, Thermophilic anaerobic oxidation of methane by marine microbial consortia: The ISME Journal, v. 5, p. 1946-1956. https://doi.org/10.1038/ismej.2011.77.

Hose, L.D., Palmer, A.N., Palmer, M.V., Northup, D.E., Boston, P.J., and DuChene H.R., 2000, Microbiology and geochemistry in a hydrogensulphide-rich karst environment: Chemical Geology, v. 169, p. 399-423. https://doi.org/10.1016/S0009-2541(00)00217-5.

Hose, L.D., and Pisarowicz, J.A., 1999, Cueva de Villa Luz, Tabasco, Mexico: reconnaissance study of an active sulfur spring cave and ecosystem: Journal of Cave and Karst Studies, v. 61, no. 1, p. 13-21.

Hu, Shihu, Zeng, R.J., Keller, J., Lant, P.A., and Yuan, Zhiguo, 2011, Effect of nitrate and nitrite on the selection of microorganisms in the denitrifying aerobic methane oxidation process: Environmental Microbiology Reports, v. 3, no. 3, p. 315-319. https://doi.org/10.1111/j.1758-2229.2010.00227.x.

Hutchens, E., Radajewski, S., Dumont, M.G., McDonald, I.R., and Murrell, J.C., 2004, Analysis of methanotrophic bacteria in Movile Cave by stable isotope probing: Environmental Microbiology, v. 6, no. 2, p. 111-120. https://doi.org/10.1046/j.1462-2920.2003.00543.x.

Jones, D.S., Albrecht, H.L., Dawson K.S., Schaperdoth, I., Freeman, K.H., Pi, Yundan, Pearson, A., and Macalady, J.L., 2012, Community genomic analysis of an extremely acidophilic sulfur oxidizing biofilm: The ISME Journal, v. 6, p. 158-170. https://doi.org/10.1038/ismej.2011.75.

Keith, M.L., and Weber, J.N., 1964, Carbon and oxygen isotope composition of selected limestones and fossils: Geochimica et Cosmochimica Acta, v. 28, p. 1787-1816. https://doi.org/10.1016/0016-7037(64)90022-5.

Kirkland, D.W., and Evans, R., 1976, Origin of limestone buttes, gypsum plain, Culberson County, Texas: AAPG Bulletin, v. 60, no. 11, p. 20052018.

Knauth, L.P., and Kennedy, M.J., 2009, The late Precambrian greening of the earth: Nature, v. 460, p. 728-732. https://doi.org/10.1038/nature08213.

Lennon, J.T., Nguyễn-Thùy, D., Phạ, T.M., Drobniak, A., Tạ, P.H., Phạm, N.Đ., Streil, T., Webster, K.D., and Schimmelmann, A., 2016, Microbial contributions to subterranean methane sinks: Geobiology. https://doi.org/ 10.1111/gbi.12214.

Liu, Q.Y., Worden, R.H., Jin, Z.J., Liu, W.H., Li, J., Gao, B., Zhang, D.W., Hu, A.P., and Yang, C., 2014, Thermochemical sulphate reduction (TSR) versus maturation and their effects on hydrogen stable isotopes of very dry alkane gases: Geochimica et Cosmochimica Acta, v. 137, p. 208-220. https://doi.org/10.1016/j.gca.2014.03.013.

Machel, H.G., 1998, Gas souring by thermochemical sulfate reduction at 140 degrees C: Discussion: AAPG Bulletin, v. 82, no. 10, p. 1870-1873.

Machel, H.G., 2001, Bacterial and thermochemical sulfate reduction in diagenetic settings - old and new insights: Sedimentary Geology, v. 140, p. 143-175. https://doi.org/10.1016/S0037-0738(00)00176-7.

Malinverno, A., and Pohlman, J.W., 2011, Modeling sulfate reduction in methane hydrate-bearing continental margin sediments: Does a sulfate sulfate-methane transition require anaerobic oxidation of methane?: Geochemistry, Geophysics, Geosystems, v. 12, no. Q07006. https://doi. org/10.1029/2011GC003501.

Mattey, D.P., Fisher, R., Atkinson, T.C., Latin, J.-P., Durrell, R., Ainsworth, M., Lowry, D., and Fairchild, I.J., 2013, Methane in underground air in Gibraltar Karst: Earth and Planetary Science Letters, v. 374, p. 71-80. https://doi.org/10.1016/j.epsl.2013.05.011.

McDonough, L.K., Iverach, C.P., Beckman, S., Manfield, M., Rau, G.C., Baker, A., and Kelly, B.F.J., 2016, Spatial variability of cave-air carbon dioxide and methane concentrations and isotopic compositions in a semiarid karst environment: Environmental Earth Sciences, v. 75, no. 700. https://doi.org/10.1007/s12665-016-5497-5.

Meneses-Rocha, J.J., 2001, Tectonic evolution of the Ixtapa Graben, an example of a strike-slip basin of Southeastern Mexico: implications for regional petroleum systems, in Bartolini, C., Buffler, R.T., and CantúChapa, A., eds., The Western Gulf of Mexico Basin: Tectonics Sedimentary Basins and Petroleum Systems: AAPG Memoir, v. 75, p. 183-216.

Mikaloff Fletcher, S.E., Tans, P.P., Bruhwiler, L.M., Miller, J.B., and Heimann, M., 2004, $\mathrm{CH}_{4}$ sources estimated from atmospheric observations 
of $\mathrm{CH}_{4}$ and its ${ }^{13} \mathrm{C} /{ }^{12} \mathrm{C}$ isotopic ratios: 1 . Inverse modeling of source processes: Global Biogeochemical Cycles, v. 18 (GB4004). https://doi.org/ 10.1029/2004GB002223.

Miller, J.B., Mack, K.A., Dissly, R., White, J.W.C., Dlugokencky, E.J., and Tans, P.P., 2002, Development of analytical methods and measurements of ${ }^{13} \mathrm{C} /{ }^{12} \mathrm{C}$ in atmospheric $\mathrm{CH}_{4}$ from the NOAA Climate Monitoring and Diagnostics Laboratory Global Air Sampling Network: Journal of Geophysical Research, v. 107, no. D13, p. ACH 11-1-ACH 11-15. https://doi.org/10.1029/2001JD000630.

Nencetti, A., Tassi, F., Vaselli, O., Macías, J.L., Magro, G., Capaccioni, B., Minissale, A., and Mora, J.C., 2005, Chemical and isotopic study of thermal springs and gas discharges from Sierra de Chiapas, Mexico: Geofísica Internacional, v. 44 , no. 1, p. 39-48

Pantoja-Alor, J., 1989, Informe geológico minero de la Mina de Sta. Fe, Chis, in Salas, G.P., ed., Geologia Económica de Mexico, p. 413-420.

Peryt, T.M., Durakiewicz, T., Peryt, D., and Pobrezhsky, A., 2012, Carbon and oxygen isotopic composition of the Middle Miocene Badenian gypsumassociated limestones of West Ukraine, Geologica Acta, v. 10, no. 4, p. 319-332. https://doi.org/10.1344/105.000001753.

Peyraube, N., Lastennet, R., Denis, A., and Malaurent, P., 2013, Estimation of epikarst air $P_{\mathrm{CO}_{2}}$ using measurements of water $\delta^{13} \mathrm{C}_{\mathrm{TDIC}}$, cave air $P_{\mathrm{CO}_{2}}$ and $\delta^{13} \mathrm{C}_{\mathrm{CO}}$ : Geochimica et Cosmochimica Acta, v. 118 , p. 1-17. https://doi. org/10.1016/j.gca.2013.03.046.

Peyraube, N., Lastennent, R., Denila, J., Villanueva, J.D., Houillon, N., Malaurent, P., and Denis, A., 2016, Effect of diurnal and seasonal temperature variation on Cussac cave ventilation using $\mathrm{CO}_{2}$ assessment: Theoretical and Applied Climatology 2016. 14 p. https://doi.org/10.1007/ s00704-016-1824-8.

Pohlman, J.W., Riedel, M., Bauer, J.E., Canuel, E.A., Paull, C.K., Lapham, L., Grabowski, K.S., Coffin, R.B., and Spence, G.D., 2013, Anaerobic methane oxidation in low-organic content methane seeps: Geochimica et Cosmochimica Acta, v. 108, p. 184-201. https://doi.org/10.1016/j.gca. 2013.01.022.

Rey, A., Etiope, G., Belelli-Marchesini, L., Papale, D., and Valentini, R., 2012, Geological carbon sources may confound ecosystem carbon balance estimates: Evidence from a semi-arid steppe in the southeast of Spain. Journal of Geophysical Research Biogeosciences 117 (G03034), https:// doi.org/10.1029/2012JG001991

Rosales Lagarde, L., 2013, Sulfidic Karst Springs and Speleogenesis in the Sierra de Chiapas. Austin, Association for Mexican Cave Studies bulletin 24, $79 \mathrm{p}$.

Rosales Lagarde, L., Boston, P.J., Campbell, A.R., Hose, L.D., Axen, G., and Stafford, K.W., 2014, Hydrogeology of northern Sierra de Chiapas, Mexico: a conceptual model based on a geochemical characterization of sulfide-rich karst brackish springs: Hydrogeology Journal, v. 22, no. 6, p. 1447-1467. https://doi.org/10.1007/s10040-014-1135-z.

Rosales Lagarde, L., Boston, P.J., Campbell, A., and Stafford, K.W., 2006, Possible structural connection between Chichón Volcano and the sulfurrich springs of Villa Luz Cave (a.k.a. Cueva de las Sardinas), Southern Mexico, in Ramón Espinasa-Pereña and John Pint, eds., Proceedings of the $\mathrm{X}, \mathrm{XI}$, and XII International Symposia on Vulcanospeleology. Austin, Association for Mexican Cave Studies bulletin 19, p. 177-184.

Sarbu, S.M., Kane, T.C., and Kinkle, B.K., 1996, A chemoautotrophically based cave ecosystem: Science, v. 272, no. 5270, p. 1953-1955. https:// doi.org/10.1126/science.272.5270.1953.

Schoell, M., 1980, The hydrogen and carbon isotopic composition of methane from natural gasses of various origins: Geochimica et Cosmochimica Acta, v. 44, no. 5, p. 649-661. https://doi.org/10.1016/0016-7037(80)90155-6.

Schoell, M., 1988, Multiple origins of methane in the Earth, in Schoell, M., ed., Origins of Methane in the Earth: Chemical Geology, v. 71, p. 1-10. https://doi.org/10.1016/0009-2541(88)90101-5.

Spilde, M.N., Fischer, T.P., Northup, D.E., Turin, H.J., and Boston, P.J., 2004 , Water, gas, and phylogenetic analyses from sulfur springs in Cueva de Villa Luz, Tabasco, Mexico (abst.): Geological Society of America Abstracts with Programs, v. 3, no. 5, paper 106-11.

Talukdar, S.C., Guevara, E.H., Jones, R.H., Galindo, A., Romero, M.A., Wawrzyniec, T.F., Villanueva, L., Khaled, F., Ambrose, W.A., Jennette, D.C., Dunlap, D.B., Meneses-Rocha, J.J., Sánchez-Barreda, L., and Lugo, J.E., 2002., Hydrocarbon source and charge in the Neogene in the Macuspana and Veracruz Basins, Mexico: Gulf Coast Association of Geological Societies Transactions, v. 52, p. 925-934.

Thom, M., Bösinger R., Schmidt, M., and Levin, I., 1993, The regional budget of atmospheric methane of a highly populated area: Chemosphere, v. 26, p. 143-160. https://doi.org/10.1016/0045-6535(93)90418-5.

U.S. Geological Survey World Energy Assessment Team, 2000, U.S Geological Survey World Petroleum Assessment 2000: U.S. Geological Survey Digital Data Series DDS, 60, 4 CDROMs.

Webster, K.D., Mirza, A., Deli, J.M., Sauer, P.E., and Schimmelmann, A., 2016. Consumption of atmospheric methane in a limestone cave in Indiana, USA: Chemical Geology, v. 443, p. 1-9. https://doi.org/10.1016/j. chemgeo.2016.09.020.

Whiticar, M.J., 1999, Carbon and hydrogen isotope systematics of bacterial formation and oxidation of methane: Chemical Geology, v. 161, p. 291314. https://doi.org/10.1016/S0009-2541(99)00092-3.

Worden, R.H., Smalley, P.C., and Oxtoby, N.H., 1995, Gas sourcing by thermochemical sulfate reduction at $140{ }^{\circ} \mathrm{C}$ : AAPG Bulletin, v. 79 , no. 6 , p. $854-863$. 